\title{
НИЖНИЙ КУЛЬТУРНЫЙ ГОРИЗОНТ ПАМЯТНИКА КАМЕННОГО ВЕКА ЭКИБАСТУЗ-4
}

\author{
(C) 2020 г. В. С. Волошин
}

В статье даётся описание памятника каменного века Экибастуз-4, приводятся стратиграфические и геоморфологические данные, описана коллекция артефактов из качественного кварцита эоцена, полученная в зачистке 1988 г. из нижнего культурного горизонта. Даётся характеристика специфического типа индустрии, для которой свойственны: в первичном расщеплении - сочетание нижне-среднепалеолитических приёмов скалывания отщепов и верхнепалеолитических приёмов снятия пластин, во вторичном расщеплении - тейякский компонент, широкое развитие техники рассечения заготовок и комбинаторика рабочих частей (элементов) орудий, серия специфических вкладышевых орудий из отщепов, а также крупных и грубых рубящих орудий. Приводятся аргументы в пользу геологического возраста индустрии как позднекаргинского - раннесартанского.

Ключевые слова: археология, Экибастуз-4, памятник, индустрия, орудие, рабочая часть, ретушь, слой, верхний палеолит, техника

\section{Введение}

Открытые местонахождения каменного века на западном побережье озера Экибастуз к юго-востоку от угольного разреза «Северный» отличаются редким богатством археологического материала. Среди развалин построек Старого Экибастуза последний залегает, практически, непрерывной площадью на протяжении сотен метров, делая границы между выделенными здесь пунктами чисто условными, а в ближайшем окружении образует локальные скопления, подчас также достаточно крупные. К сожалению, всё это богатство ныне, после значительного расширения угольного разреза, в значительной мере утрачено.

В геоморфологическом отношении местность представляет собой слегка всхолмлённую равнину с абсолютными отметками 180-200 м, сформированную на породах палео-

гена и возвышающуюся над днищем солёного озера на 18-19 м; стоянкимастерские древнего человека располагались вблизи или непосредственно на выходах толщи светло-серых кварцитов эоцена. В ходе работ нашей экспедиции в 1988 г. основные сборы археологического материала производились на памятнике Экибастуз-1, расположенном в ложбине в стороне от развалин домов, а также в Экибастузе-2, условном пункте среди развалин бывших городских построек.

\section{Описание материала}

Предметом нашего внимания здесь является другой памятник, а именно условно выделенный пункт Экибастуз-4, расположенный в 300 м от берега озера и в 530 м к юго-западу от ближайшего тригопункта с отметкой 193 м и привязанный к заброшенному котловану и выбросам из него 
(рис. 1, A). В 1988 г. здесь, помимо выборочного сбора археологического материала, была произведена зачистка стенки котлована длиной 6 м и глубиной 2 м. Результатом стало получение необходимого стратиграфического профиля (рис. 1, Б), а также новых коллекций артефактов каменного века.

В основании стратиграфическогопрофиля памятника находится пласт светло-серых тонко-мелкозернистых кварцитовидных песчаников эоцена. Выше залегает толща рыхлых, пы-

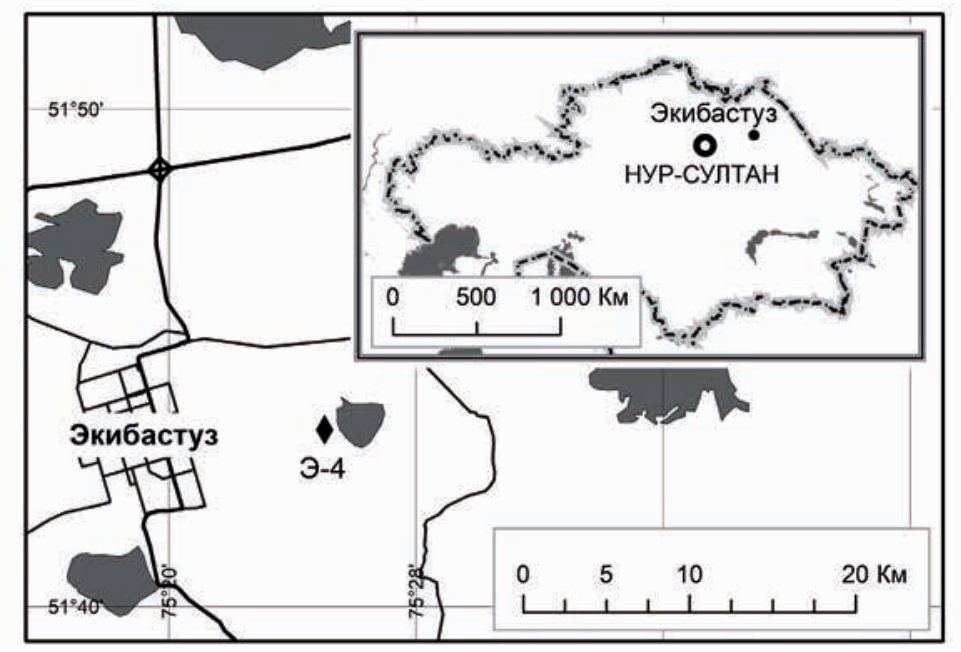

A

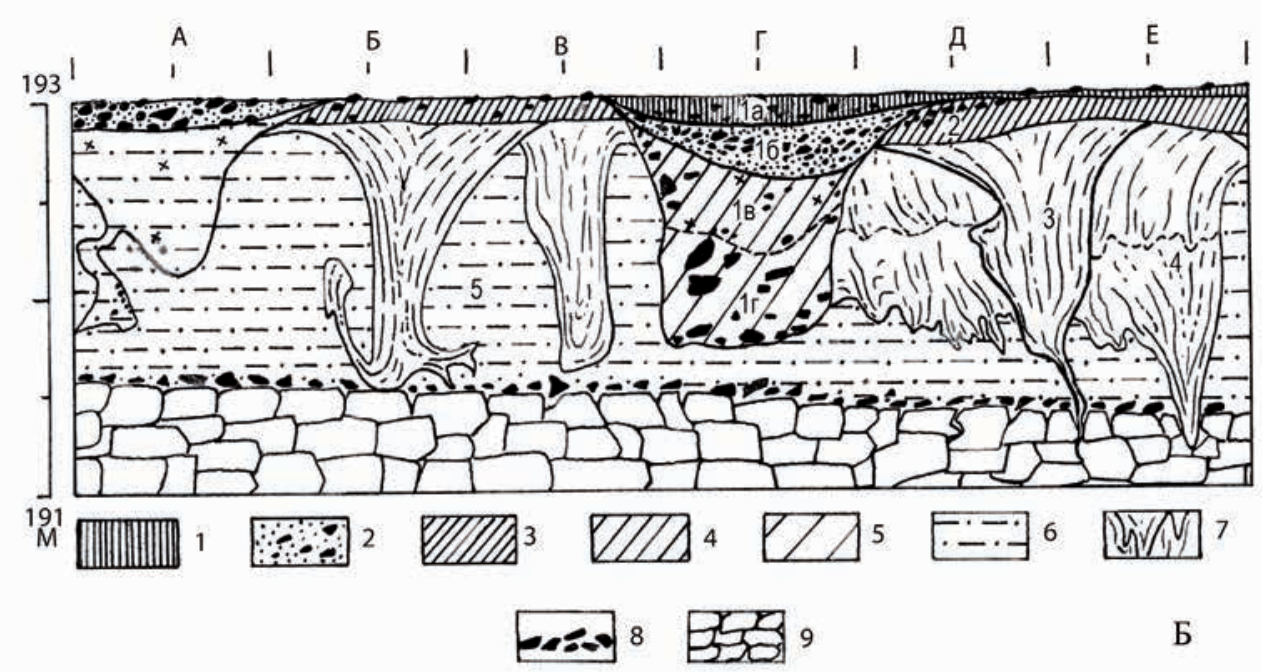

Рис. 1. Экибастуз-4. А - локализация памятника; Б-стратиграфический профиль:

1 - супесь гумусированная; 2 - песок эоловый; 3 - супесь коричневато-бурая;

4 - супесь с щебнем; 5 - щебень с супесью; 6 - супесь палевая; 7 - криогенные образования; 8 - кваричитовые обломки, блоки и артефакты;

9 - пласт эоиеновых кваричитов

Fig. 1. Ekibastuz-4. A - localization; 5 -stratigraphic profile: 1 - humous sand clay;

2 - aeolian sand; 3 - brownish-brown sand clay; 4 - sand clay with crushed stone;

5 - crushed stone with sand clay; 6 - straw-colored sand clay; 7 - cryogenic formations; 8 -quartzite debris, blocks and artifacts; 9 -Eocene quartzite formation 
леватых отложений (пески, супеси и суглинки) мощностью не более $1,5 \mathrm{M}$ с базальным грубообломочным элювиальным горизонтом и разрушенная сверху несколькими (2-3) генерациями полигональных криогенных клиновидных трещин. В эту толщу вложены заполнения древней траншеи, вырытой, очевидно, уже в голоцене в целях добычи ценного качественного сырья (кварцитов). Траншея, вероятно, соответствует чёткому культурному горизонту в верхней части слоя коричневато-бурой супеси (слой 2): данный слой перекрывает указанную выше толщу и местами, в свою очередь, перекрывается маломощными осадками - светлыми эоловыми песками и супесями, а также тёмносерой гумусированной супесью (современной почвой). Таким образом, на памятнике выделены следующие слои (сверху вниз):

1а - супесь тёмно-серая гумусированная мощностью до 20 см, залегает линзой на месте древней траншеи, содержит отдельные кварцитовые артефакты;

16 - песок и супесь светлосерые эоловые мощностью до $30 \mathrm{~cm}$, залегает также линзами поверх заполнений траншеи, а также заполнений одной из клиновидных трещин (самой поздней), содержит многочисленные кварцитовые артефакты, скорее всего, переотложенные из указанного выше слоя коричневато-бурой супеси;

1в - супесь коричневато-бурая с обилием щебня кварцитов мощностью до $40 \mathrm{~cm}$, представляет собой верхнюю часть заполнений древней траншеи, содержит редкие кварцитовые артефакты;

$1 \Gamma-$ супесь коричневато-серая с бурым оттенком, включает кварцитовый щебень и артефакты мощностью до 55 см, представляет собой нижнюю часть заполнений древней траншеи;

2 - супесь коричневато-бурая мощностью до $23 \mathrm{~cm}$, в верхней части содержит культурный горизонт из кварцитовых артефактов мощностью около 5-7 см;

3 - супесь и песок серые карбонатизированные, являются заполнением верхней генерации криогенных клиньев, без артефактов;

$$
4 \text { - супесь и суглинок }
$$
коричневато-серые сильно карбонатизированные, являются заполнением нижней генерации криогенных клиньев;

5 - супесь пылеватая коричневато-палевая неслоистая, карбонатизированная мощностью до 1,2 м, в основании - грубообломочный элювиальный горизонт из кварцитов мощностью до 10 см, к которому приурочен нижний культурный горизонт: слой залегает поверх пласта эоценовых кварцитов.

Каменная индустрия нижнего горизонта Экибастуз-4

В зачистке из нижнего культурного горизонта получена коллекция из 220 кварцитовых артефактов, которая, безусловно, является выборкой, поскольку мелкие обломки и сколы (меньше 3 см) в данном случае не брались и не учитывались при раскопках и таковых было, по меньшей мере, вдвое больше отобранных предметов. Сырьём для изготовления орудий служил светло-серый тонкозернистый (значительно реже - мелкозернистый) окремнённый кварцит высокого качества, который добывался из поверхностной части эоценового пласта, подвергшейся ранее многочисленным трещинам. Для обработки использовались блоки и обломки различных размеров, нередко с острыми 
краями и углами и с поверхностями двух типов. К первому типу относятся поверхности с толстой коркой (до 5 мм) от интенсивного химического выветривания, буроватого цвета и сглаженные водной или ветровой эрозией; ко второму типу - относительно «свежие» поверхности естественных расколов тусклого серого цвета (в отличие от «блестящих» фасов) с округло-овальными коническими лунками от морозного выветривания. Фасы обработки отличаются совершенно «свежим» характером, в местах ударов просматриваются светлые «воздушные» пятнышки, имеются также небольшие лунки от морозного выветривания; края изделий обычно острые. Достаточно часто на изделиях наблюдаются налепы сгустков кристаллов гипса, большая часть которых связана с поверхностями первого типа; присутствуют они и на поверхностях обработки фасов.

В коллекции имеются нуклеусы и нуклевидные предметы (4 экз.), отщепы и пластины (30 экз.), вспомогательные сколы (30 экз.) и орудия труда (156 экз.).

Нуклеусов всего 3 экз. Первый из них отличается особенно крупными размерами $(19,7 \times 12,7 \times 5,0$ см $)$ и представляет собой вариант одноплощадочного одностороннего плоскостного продольного приготовленного нуклеуса (рис. 2, 1). Он оформлен достаточно грубо: боковыми широкими крутыми и отвесными фасами с лицевой стороны и более пологими фасами на одном боку с обратной стороны. Нижний конец сужен и заострён небольшими двухсторонними фасами. Скошенная ударная площадка оформлена 3-4 фасами. Изделие фиксирует начальную стадию утилизации: широкий и короткий фронтальный фас от основного отщепа, в свою очередь, вместе с рядом наложенных на него небольших плоских фасов и фасеток предопределяют последующее вероятное снятие короткого основного отщепа с острым краем и боковым обушком-гранью - формы, характерной для данной индустрии. Второй нуклеус также отличается крупными размерами $(16,5 \times 12,2 \times 4,8$ см). Он изготовлен из расколотого блока и относится к группе краевых продольных ядрищ (рис. 2, 2). Здесь примечательна манера оформления изделия, весьма характерная для оформления орудий в данной индустрии, а именно использование в этих целях поперечных расколов и широких (равным образом и небольших) сечений на краях, углах и окончаний изделий (это не исключало дополнительное нанесение уплощающих фасов и фасеток). Ударная площадка нуклеуса прямая и гладкая. Для снятия пластин использовался посредник. Третий нуклеус небольших размеров относится также к группе продольных краевых ядрищ (рис. 3, 3). Из-за скошенной (гладкой) площадки и фасеток уплощения латералей, направленных от площадки, его легко принять за тип клиновидного ядрища, однако, внимательный осмотр заметит здесь отсутствие каких-либо признаков намеренного приготовления клина. При оформлении и расщеплении данного нуклеуса также использовался посредник. Помимо трёх нуклеусов в коллекции имеется один небольшой нуклевидный предмет со следами фасов и фасеток («преформа»).

В группе отщепов и пластин (30 экз.) имеются отщепы не-леваллуа (24 экз.) и пластины (6 экз.) (рис. 4, $5,8)$. Последние почти все широкие и толстые, неправильной формы, 

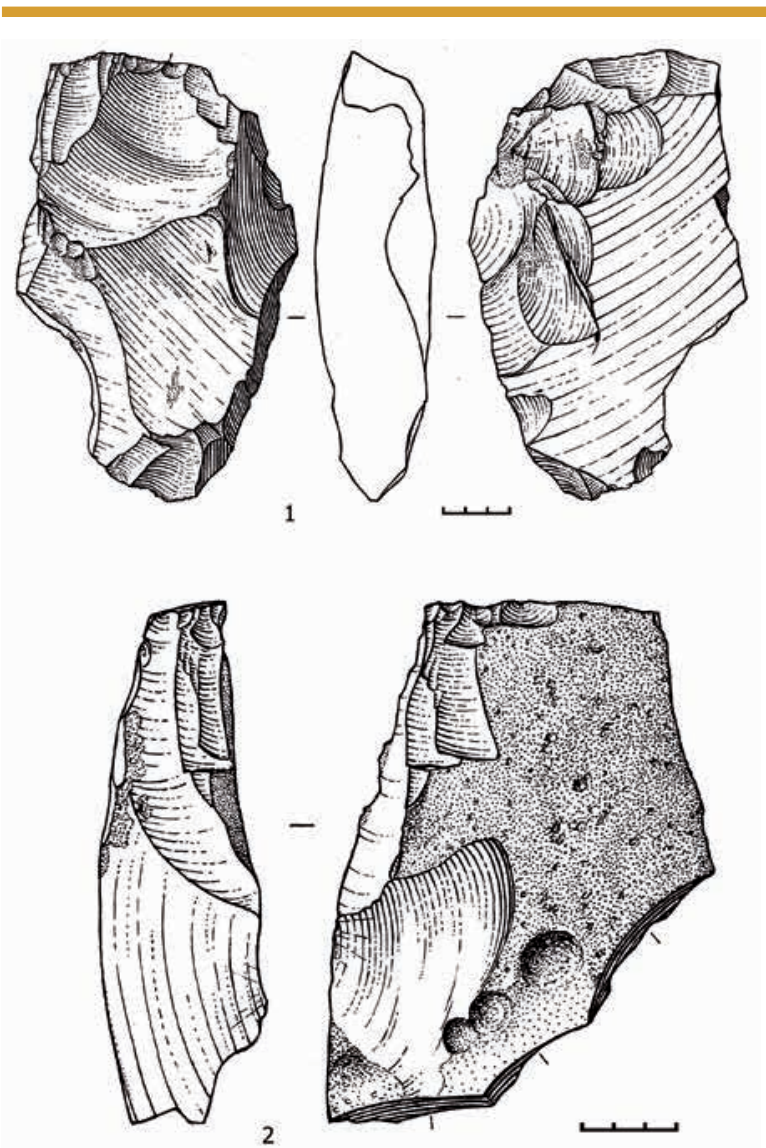

Рис. 2. Экибастуз-4. Кваријитовые артефакты: 1-2 - нуклеусы

Fig. 2. Ekibastuz-4. Quartzitic artifacts. 1-2-nucleus

треугольные в поперечнике, иногда с выраженной стрелкой прогиба, со скошенной гладкой площадкой и небольшим бюльбом (сняты без посредника с помощью тяжёлого и лёгкого отбойников). Есть одна массивная реберчатая пластина. Среди орудий имеется ещё пять пластин (включая фрагменты и сечения) со следами вторичной обработки - они мало чем отличаются от форм, описанных выше, одна пластина снята с помощью посредника.

Таким образом, индустрия Экибастуза-4 не является пластинчатой. Основная масса орудий из- готовлена здесь из отщепов и сколов (123 экз.), меньшая часть - из обломков (32 экз.) и только одно орудие - из широкой пластины. Вместе с тем эта индустрия - нелеваллуазская и не клектонская. Из 153 сколов-заготовок (включая орудия) к леваллуазским (черепаховидным) относятся только два (рис. 4, 2), а к клектонским - всего шесть отщепов (рис. 4, 1). Из 127 отщепов и пластин более половины (68,5\%) сняты с помощью тяжёлого отбойника и имеют бюльбы (3 пластины), остальные - с помощью мягкого отбойника - 29,1\% (3 пластины) и посредника - 2,4\% (1 пластина). Нужно иметь в виду, что хотя выборка артефактов в зачистке производилась на месте разработки залежей кварцитового сырья палеолитическим человеком, памятник этот не может быть идентифицирован как грубая мастерская. Об этом наглядно свидетельствует, с одной стороны, обилие в коллекции изделий с вторичной обработкой, с другой, характер отщепов и сколов: из 88 целых заготовок у 44 экз. (50\%) на дорзальных поверхностях отсутствуют участки естественной корки, ещё у 39 экз. (44,3\%) - они охватывают небольшую площадь; такие показатели естественны для стоянок-мастерских. Метрические данные получены у 88 целых отщепов и пластин (измерение длины заготовок проводилось по оси скалывания). Длина заготовок варьирует в пределах 3-15 см, большинство (63,8\%) - в пределах 3-7 см, крупных заготовок (более $10 \mathrm{~cm}$ ) - всего 


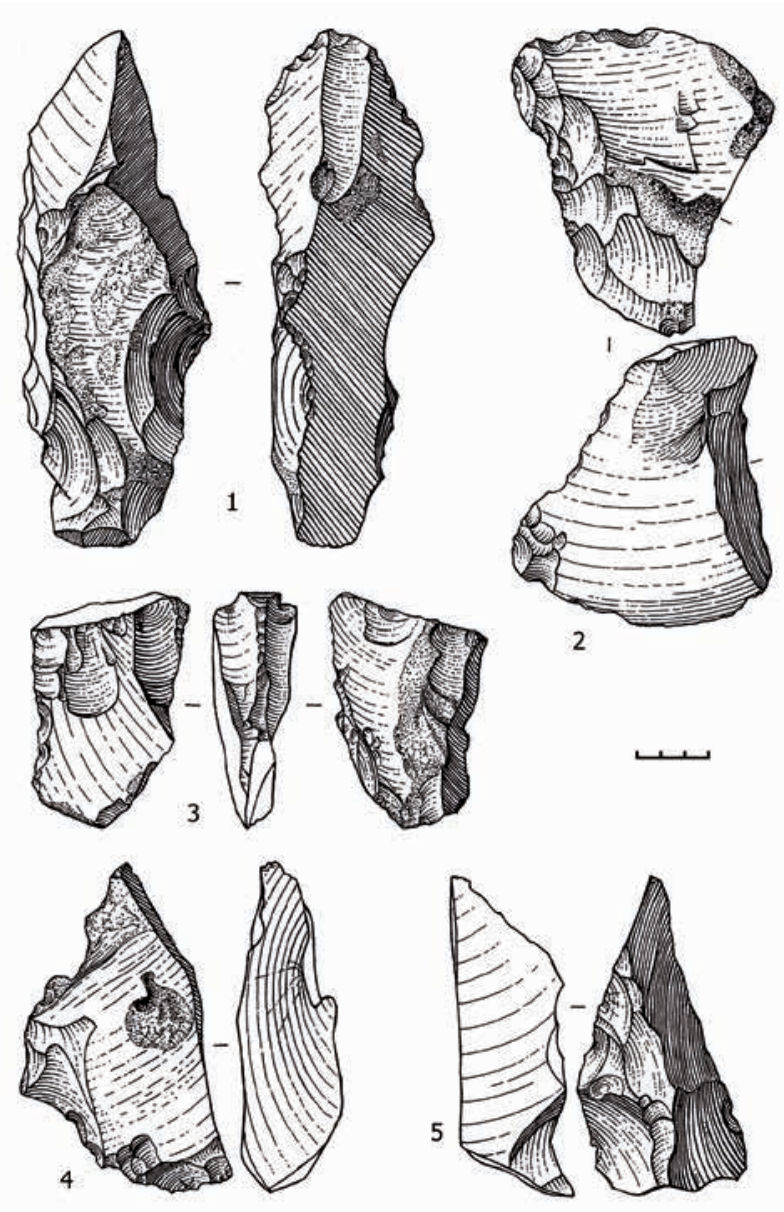

Рис. 3. Экибастуз-4. Квариитовые артефакты: 1 - орудие типа «кирка»; 2 - скребловидное орудие; 3 - нуклеус; 4-5 - крупные остроконечные орудия

Fig. 3. Ekibastuz-4. Quartzitic artifacts. 1 - "spaddle" type tool; 2 - thumb flint shaped tool; 3 - nucleus; 4-5-large pointed tools

пластины (7 шт.) составляют $8 \%$. По отношению толщины к ширине заготовок (показатель массивности) большинство изделий $(63,6 \%)$ - в пределах 0,11-0,30. По отношению длины ударной площадки к ширине заготовки большинство изделий (около 82\%) варьирует в пределах 0,31-0,90. Показатель скошенности ударных площадок к нижней поверхности даёт следующие величины: прямые и слегка скошенные площадки (2 пластины) - 39\%, скошенные площадки $\left(100-130^{\circ}\right)-46 \%$ (3 пластины), сильно скошенные площадки (4 пластины) - 15\%. Абсолютно доминируют гладкие площадки (67\%), двухгранные - 17\%, грубофасетированные - 9,2\%, тонко-фасетированные - 0,9\%, натуральные $2,5 \%$, микроплощадки $3,4 \%$. Таковы основные характеристики первичного расщепления в данной индустрии.

Исходными за-

10\%. Ширина заготовок - в пределах 2-11 см, большинство (67\%) - в пределах 3-7 см. Толщина заготовок - в пределах 0,5-4,0 см. Тонкие заготовки (до 1 см) составляют $30 \%$, средние $(1,1-2,0$ см $)-45,5 \%$, толстые $(2,1-$ 3,0 см) - 20\% и очень толстые (свыше 3 см) $-4,5 \%$. По отношению длины к ширине заготовок (показатель удлинённости) большинство изделий (60,2\%) варьирует в пределах 0,7-1,3, готовками для изготовления орудий служили отщепы и сколы (122 шт.), обломки (32 шт.) и пластины (2 шт.). К крупным орудиям, размерами более 10 см, относится 12 изделий, почти все они изготовлены из обломков кварцита. Опишем их по отдельности.

Удлинённое двухконечное орудие типа кирки $(21,2 \times 7,8 \times 6,4$ см) грубо оформлено редкими фасами на 


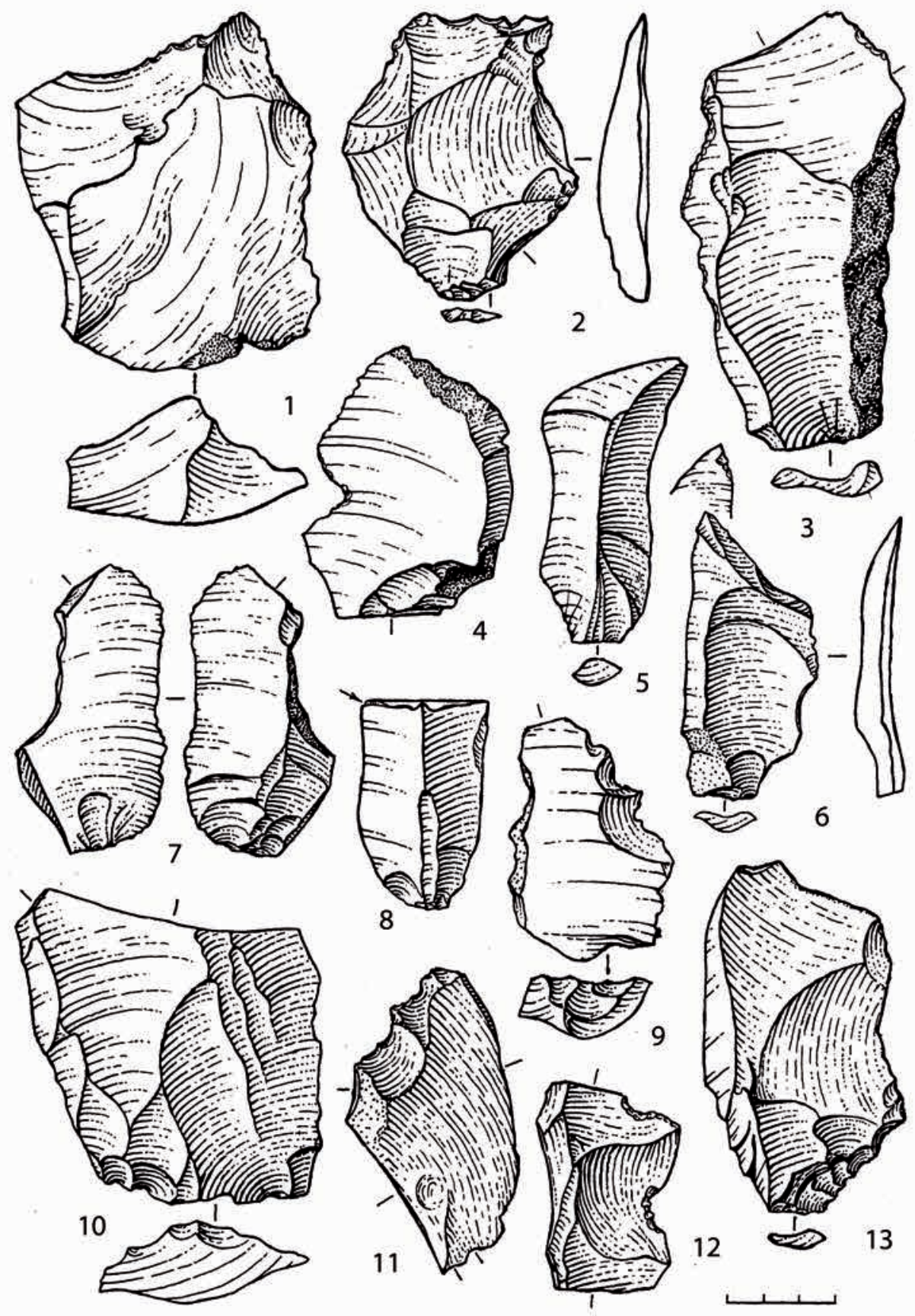

Рис. 4. Экибастуз-4. Квариитовые артефакты: 1 - крупное режущее орудие; 2 - угловой резчик; 3, 4, 7-ножи; 5, 8- пластины; 6- проколка; 9 - зубчатый нож; 10 - режущее орудие; 11 - зубчатый скобель; 12 - выемчатьй скобель; 13 - скребло

Fig. 4. Ekibastuz-4. Quartzitic artifacts: 1 - large cutting tool; 2 - angular cutter; 3, 4, 7 -knives; 5, 8 -plates; 6 - piercer; 9 -serrate knife; 10 -cutting tool; 11 - serrate scraper; 12 - retuse scraper; 13 - thumb flint 
краях, в поперечнике - подтреугольное. Лезвие на верхнем конце сильно закругленное и оформлено односторонними пологими снятиями. Нижнее лезвие более узкое, долотовидное, острое, образовано пересечением двух плоскостей от расколов; оно ориентировано поперёк верхнему лезвию (рис. 3, 1).
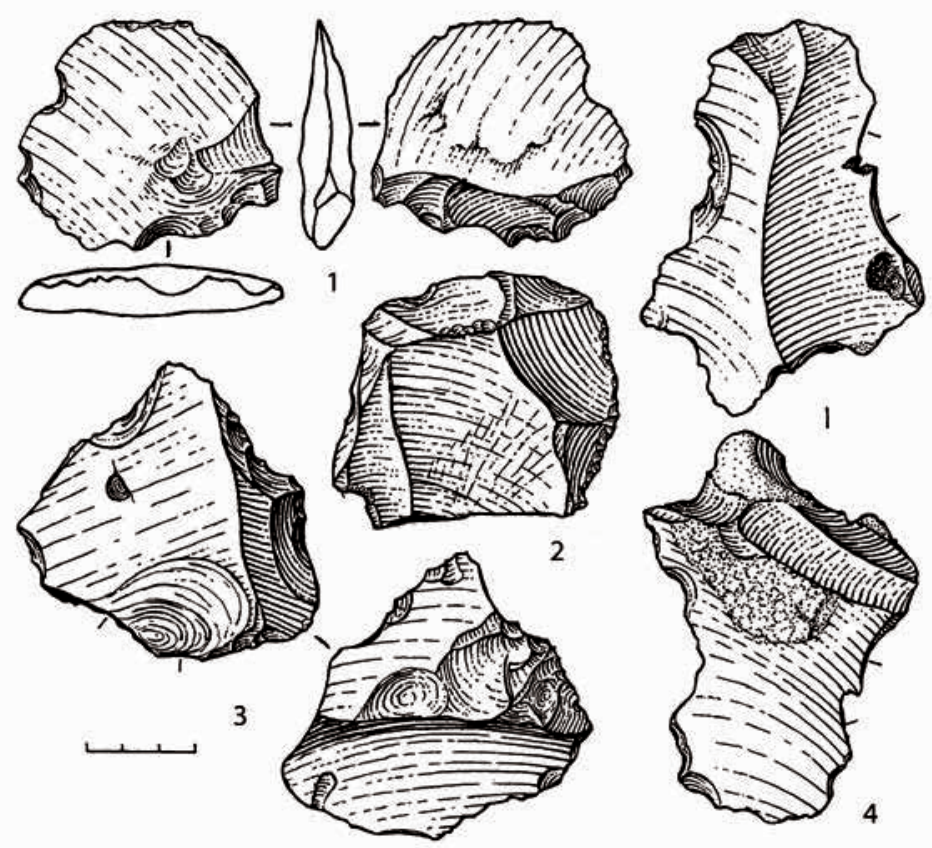

Остроко -
нечное орудие со скошенной пяткой $(14,2 \times 8,5 \times 4,2 \mathrm{~cm})$ оформлено боковым поперечным расколом и в сечении также подтреугольное. Пятка оформлена
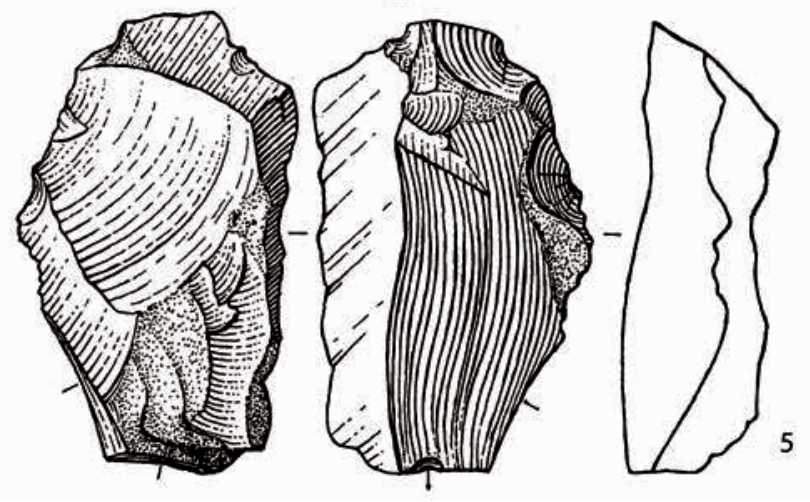
двухсторонними фасами. На окончании орудия наблюдается узкая поперечная кромка с альтернативными фасетками

Рис. 5. Экибастуз-4. Квариитовые артефакты: 1 - вкладыш из отщела; 2 - скребло; 3 - угловой резчик; 4-орудие с выступами; 5 - струг

Fig. 5. Ekibastuz-4. Quartzitic artifacts: 1 - flake insert; 2 - thumb flint; 3 - angular cutter; 4 - tool with ledges; 5 - adz ретуши (рис. 3,4$)$.

Остроконечное орудие с широкой пяткой в основании $(13,3 \times 7,0 \times 4,1 \quad$ см), в поперечнике подтреугольное, сходное с остриём кинсон; орудие грубо оформлено несколькими фасами (рис. 3,5 ).

Орудие с поперечным лезвием типа струга $(12,5 \times 7,4 \times 4,1$ см) имеет

массивный боковой обушок (плоскость раскола) и оформлено скупо - фасами на одном боковом краю. Лезвие прямое и достаточно узкое (2,6 см), по бокам выделено двумя нижними фасами и смещено к нижней стороне (рис. 5, 5). 
Волошин B.C. Нижний культурный горизонт памятника каменного века Экибастуз-4

Орудие типа сечки

$(11,9 \times 10,4 \times 3,0 \quad$ см $)$ подтреугольной формы с боковым обушком от поперечного раскола и с прямым лезвием со следами ретуши и с угловым выступом. Орудие дополнительно осложнено широким выступом скребущего профиля (1,7 см), выделенным с боков глубокими выемками, а также угловой поперечной резцевидной кромкой.

Орудие с боковым выпуклым рубящим-режущим лезвием, образованным от пересечения двух лицевых плоскостей расколов с нижней поверхностью $(13,4 \times 8,2 \times 3,0$ см $)$. Один из концов орудия наискось усечён и имеет фасетки утончения.

Удлинённое двухконечное орудие с боковым натуральным обушком $(15,2 \times 4,9 \times 3,0$ см). На одном из концов орудия скупо оформлено трёхгранное в поперечнике остриё с коротким резцовым сколом на окончании. На другом конце - толстое клювовидное острие (угловой резчик), оформленное клектонской выемкой и противолежащей притупливающей ретушью (рис. 6, 5).

Орудие с рабочими элементами $(10,9 \times 7,7 \times 3,1$ см): боковым выступом в форме трёхгранного зуба, оформленного с боков глубокими выемками-фасетками; массивным выступом с диагональной режущей кромкой на окончании, оформленной небольшими фасетками (рис. 5, 4). Данное орудие оформлено на боку двумя небольшими вогнутыми сечениями, а на более тонком конце рядом небольших выемок-фасеток, формирующих извилистый острый край; последний мог служить режущим лезвием или вставляться в рукоять составного орудия.
Орудие с двумя боковыми крупными выемками (2,5 и 2,9 см), оформленными чешуйчатыми фасетками ретуши (скобель). Орудие грубо оформлено поперечными фасами и сечениями $(14,3 \times 5,8 \times 2,7$ см).

Фрагмент остроконечного рубящего орудия подтреугольной формы с лицевым срединным ребром (треугольное в поперечнике) и с пяткой в основании, последняя оформлена двумя отвесными фасами. Обработке также подверглось окончание орудия несколькими пологими фасами частично с двух сторон. Длина орудия превышала 17 см, ширина $-11,8$ см, толщина $-4,5$ см.

Рубящее - скребловидное орудие из отщепа с угловатым лезвием, оформленным отёсывающей ретушью, преимущественно дорзальной $(10,4 \times 11,6 \times 3,0$ см), и противолежащим обушком от широкого поперечного раскола-сечения (рис. 3,2 ).

Режущеебоковоеорудиеизклектонского отщепа $(10,2 \times 7,9 \times 3,2$ см $)$ с угловатым гранёным обушком. Режущее лезвие на верхнем конце граничит с острым выступом, отделяющим его от концевого вогнутого лезвия скребла с лёгкой дорзальной ретушью (рис. 4,1$)$. Грани данного орудия несут следы лёгкого выветривания, форма изделия к тому же имеет некоторое сходство с орудиями ашельского комплекса Вишнёвка-3, поэтому нельзя исключить возможность его более древнего возраста.

Остальные 144 орудия меньших размеров изготовлены, преимущественно, из отщепов. Прежде, чем привести описание орудий по выделенным группам, отметим следующее. Здесь в качестве заготовок использовались отщепы с одним боковым острым краем (41\%), двумя кра- 
ями (25,8\%), с дугообразным острым краем (10\%), а также с острым краем по всему периметру (10\%); остальные 13,2\% приходятся на заготовки c очень незначительным участком острого края по периметру заготовки. Использовались также обломки квар- цита (22 шт.). Одной из отличительных особенностей данной индустрии является частое использование при изготовлении орудий приёма рассечения заготовки, это касается в равной степени как отщепов, так и достаточно плоских обломков породы.
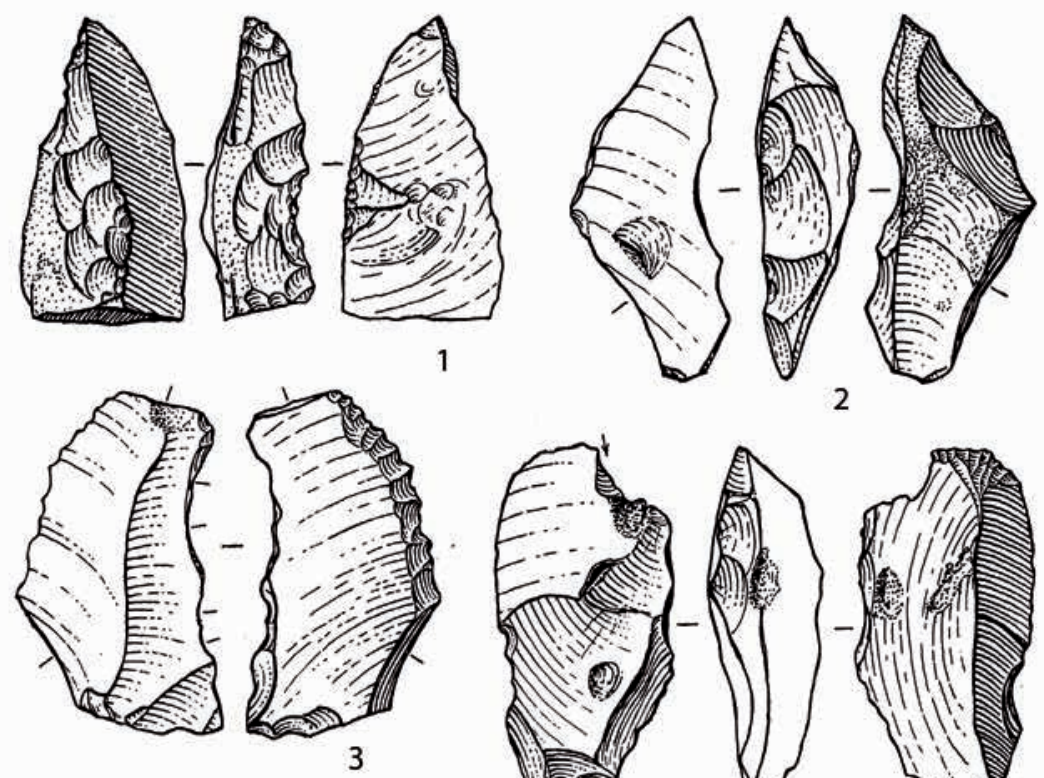

2
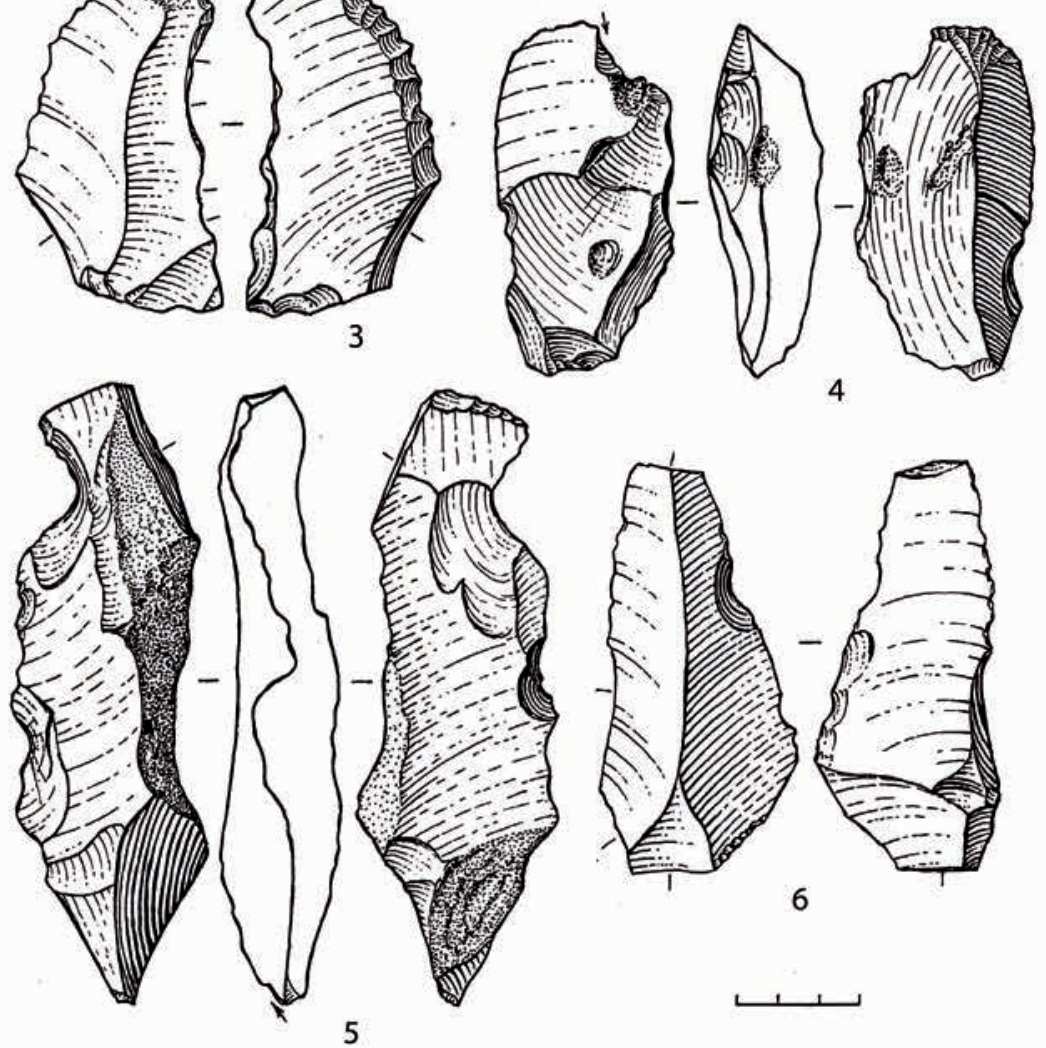

6
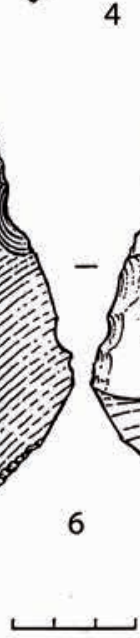

Рис. 6. Экибастуз-4. Кваричитовые артефакты: 1, 2 - остроконечники; 3 - скребло; 4 -скребок; 5 - двухконечное орудие; 6 - нож

Fig. 6. Ekibastuz-4. Quartzitic artifacts: 1, 2-pointers; 3 - thumb flint; 4 -scraper; 5 -two-point tool; 6-knife 
Волошин B.C. Нижний культурный горизонт памятника каменного века Экибастуз-4

Сечения могли быть широкими, разделяющими заготовку на две или три, примерно, равные части, а также небольшими - концевыми и боковыми или совсем маленькими, срезающими угол, или выступ на краю заготовки.

Всего подверглось сечению около $70 \%$ орудий: у 73 орудий наблюдается одно сечение, чаще всего дистальное-концевое, а у 25 орудий - более интенсивное рассечение, включающее от 2 до 4 сечёных участков края. Ещё одной отличительной чертой индустрии является удаление ударной площадки отщепа-заготовки. Последняя либо отсекалась (20 шт.), либо удалялась отдельными или несколькими фасами и фасетками (13 шт.) с одной или двух сторон. Ниже даётся описание орудий.

Описание орудий по выделеннымм группам

Двухсторонне-обработанные орудия - 1 шт. Это маловыразительное орудие, изготовленное из обломка, с частичной двухсторонней обработкой и острым слегка вогнутым поперечным лезвием (3 см) на конце, образованным от пересечения двух плоскостей расколов $(9,0 \times 6,0 \times 3,2 \mathrm{~cm})$; орудие напоминает кливер. На нижней (плоской) стороне наблюдаются небольшие (до 1 см в диаметре и глубиной в несколько мм) конусовидные лунки, вероятно, от морозного выветривания.

Орудия топоровидные или сечки - 1 шт. Это относительно небольшое $(7,5 \times 7,5 \times 2,8 \mathrm{~cm})$ орудие подтреугольной формы, весьма грубое в оформлении, с рубящим дугообразным лезвием в основании, оформленным фасетками частично с двух сторон и извилистым в профиль. Оба скошенных боковых края являются натуральными обушками.
Скрёбла - 5 шт. Здесь представлены разнообразные формы. Скребло с выпуклым лезвием на конце короткого отщепа (рис. 7, 3), комбинировано с элементом - боковой нож с обушком-гранью, утончённым вентральными фасетками. У другого изделия лезвие скребла расположено в базальной части бокового края и оформлено дорзальными пологими отёсывающими фасетками с заломами (рис. 4,13 ); орудие опять же комбинировано с элементом бокового обушкового ножа. Третье изделие представляет собой довольно крупное скребло с выпуклым лезвием, оформленным нестандартной ретушью с лицевой стороны (рис. 5, 2); в основании орудия - сечение, на уголках которого оформлены выступы скребущего профиля и с поперечной резцевидной кромкой. Четвёртое изделие - вентральное боковое выпуклое скребло, оформленное стандартной чешуйчатой ретушью (рис. 6, 3). Данное орудие представляет собой единственный в коллекции образец с такой протяжённой и ровной отделкой лезвия. Орудие комбинировано с базальным клювовидным выступом (резчиком), оформленным вентральными фасетками. Если принять во внимание наличие у данного орудия двух сечёных участков, формирующих, в частности, привершинную площадку для упора пальца руки, то становится возможной иная интерпретация «лезвия скребла» - в качестве обушка клювовидного резчика. Последнее изделие изготовлено из укороченного отщепа c отсечённой площадкой, неровное выпуклое лезвие скребла оформлено крутой дорзальной ретушью на узком боковом краю.

Остроконечники - 2 шт. Первое изделие представляет собой короткий 
и толстый образец с пяткой-гранью в основании со срединным ребром на лицевой стороне и в поперечнике - подтреугольный (рис. 6, 1). Орудие оформлено по одному боковому краю, срединному ребру и окончанию фасетками ретуши и напоминает остриё кинсон. Другое изделие - это тейякский остроконечник с толстым трёхгранным в сечении остриём, оформ-
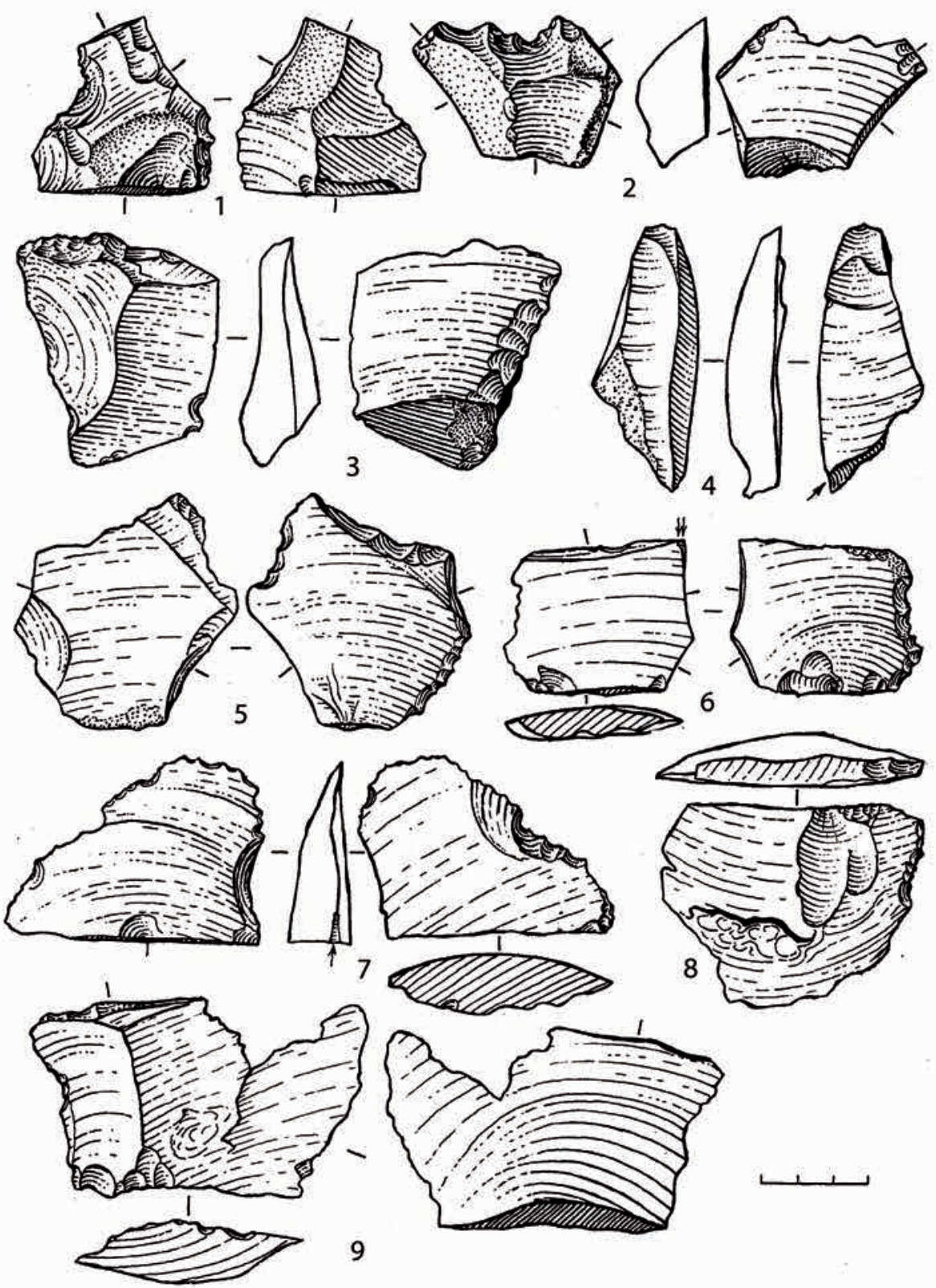

8

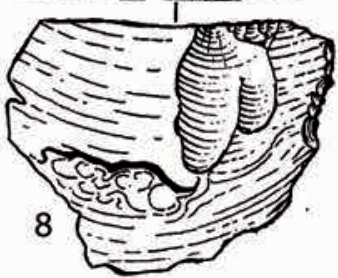

9

Рис. 7. Экибастуз-4. Кваричитовые артефакты: 1 - выемчатый скобель; 2 - зубчатый скобель; 3 - скребок; 4 -долотовидное орудие;

5, 9-угловые резчики; 6-8-вкладыши

Fig. 7. Ekibastuz-4. Quartzitic artifacts: 1 - retuse scraper; 2 - serrate scraper; 3 -scraper; 4 -chisel-shaped tool; 5, 9-angular cutters; 6-8-inserts 
Волошин B.C. Нижний культурный горизонт памятника каменного века Экибастуз-4

ленный односторонне широким боковым сечением и рядом крутых и полукрутых фасов и фасеток (рис. 6, 2). Максимальная толщина приходится на верхнюю половину орудия, нижняя часть более тонкая с фасетками ретуши на узком основании. Орудие могло крепиться к рукоятке или в торец древка копья.

Острия - проколки - 6 шт. Первое орудие (рис. 8, 5) имеет ретушированные выемки на боковых краях и
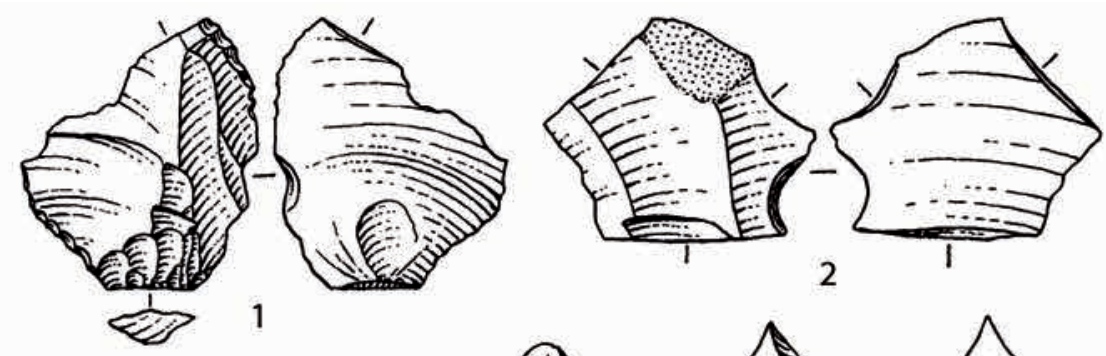

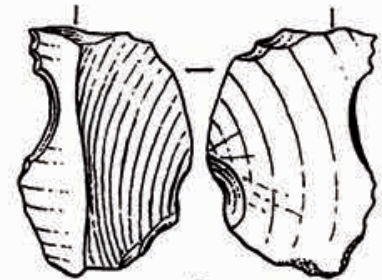

3

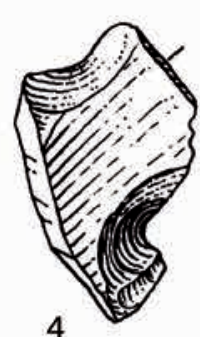

4

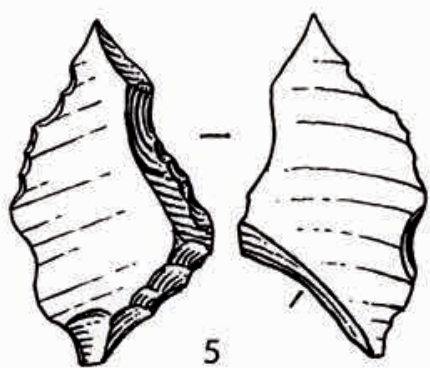

5

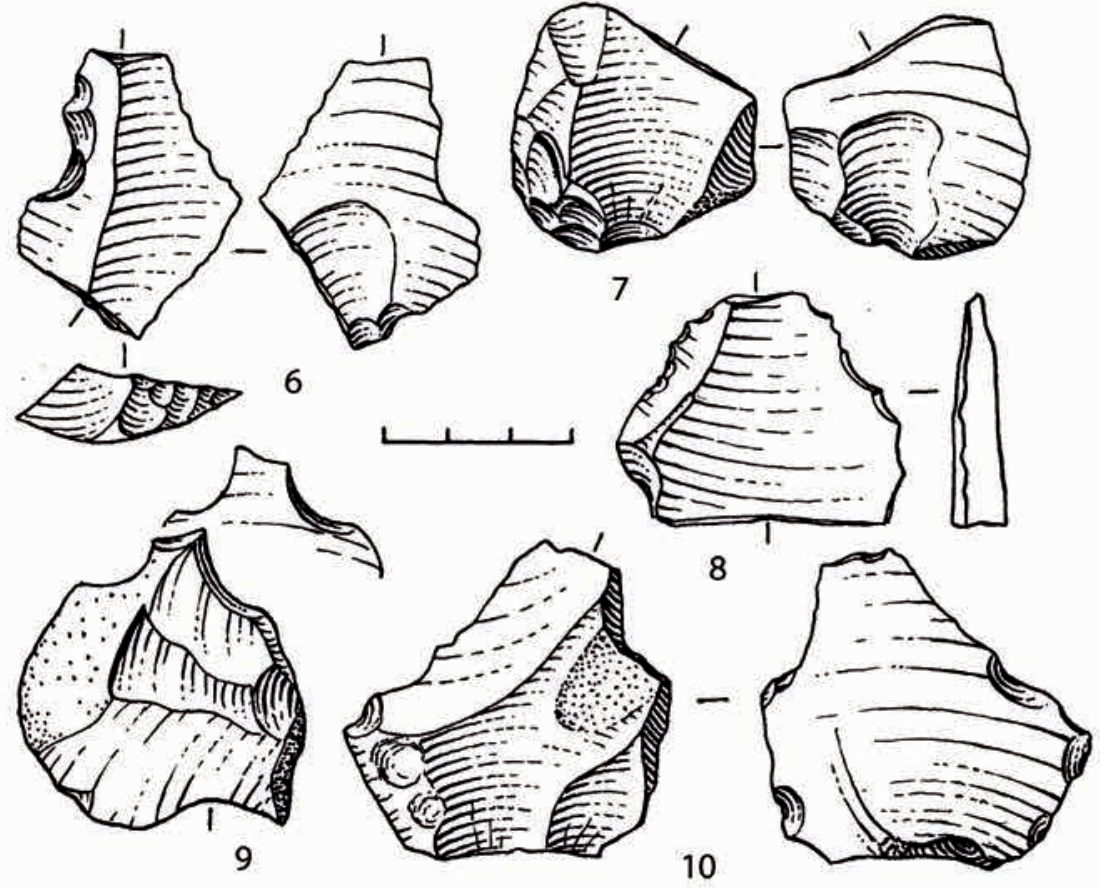

Рис. 8. Экибастуз-4. Кваричитовые артефакты: 1 - скребок; 2, 7 - сеченные формы; 3, 5, 9 - проколки; 4-выемчатый скобель; 6, 8- вкладыши; 10 -режущее орудие

Fig. 8. Ekibastuz-4. Quartzitic artifacts: 1 -scraper; 2, 7 -sectioned shapes; 3, 5,9-piercers; 4 -retuse scraper; 6, 8 -inserts; 10 -cutting tool 
комбинируется с клювовидным резчиком в основании; в базальной части имеются дорзальные фасетки утончения вогнутой поверхности сечения. Второе орудие изготовлено из плоского обломка и представляет собой проколку с коротким клювовидным жалом, оформленным двумя лицевыми и обратной выемками-фасетками (рис. 8, 9); в основании орудия - глубокая выемка от нижней фасетки. Ещё одно орудие - удлинённое трёхгранное остриё-проколка с широкой ретушированной выемкой на боковом краю. Четвёртое орудие - сходно с предыдущим, но имеет в основании натуральную пятку. Пятое орудие изготовлено из тонкого пластинчатого отщепа, снятого от посредника (рис. 4,6 ); короткое жало оформлено на дистальном угловом окончании дорзальной фасеткой и вентральной мелкой ретушью. Последнее орудие - угловая проколка из небольшого укороченного скола (рис. 8, 3); жало оформлено с боков сечением и широкой и глубокой выемкой-фасеткой, а также краевой ретушью.

Скребки - 4 шт. Первое орудие изготовлено из продолговатого массивного обломка с боковым обушком-гранью, подверглось, особенно в нижней части, некоторому оформлению с помощью отдельных фасов и фасеток, в том числе с выемкой (рис. 6, 4); лезвие выпуклое и толстое приготовлено на массивном конце полукрутой пластинчатой и крутой чешуйчатой ретушью и сбоку срезано коротким краевым резцовым сколом. У второго орудия, изготовленного из небольшого плоского отщепа, слегка выпуклое лезвие скребка оформлено чешуйчатой ретушью на боку в дистальной части (рис. 8, $1)$; лезвие ограничено с боков косым концевым сечением и вентральной выемкой-фасеткой на боковом краю. Ещё одно изделие - укороченный отщеп с угловым скребковидным лезвием от дорзальной крутой чешуйчатой ретуши, комбинируется с режущим лезвием (3,7 см) с двумя вентральными выемками-фасетками. Последнее орудие - из массивного обломка имеет также угловое скребковидное лезвие, выделенное с боку выемкойфасеткой, и комбинировано с массивным трёхгранным выступом с двухсторонними фасетками; орудие несёт следы подтёски фасетками с нижней (более плоской) стороны.

Долотовидные орудия - 1 шт. Изделие изготовлено из неправильной пластины, снятой, вероятно, от посредника (рис. 7, 4). Лезвие расположено на месте площадки, узкое и оформлено пологими фасетками с двух сторон; на дистальном окончании пластины скошенный краевой резцовый скол.

Выемчатые скобели - 4 шт. Первое орудие из обломка оформлено тремя толстыми сечениями и имеет широкую клектонскую выемку (рис. 7, 1); на противоположном краю - неровно ретушированное лезвие скребущего профиля. Второе орудие - также из обломка, имеет две ретушированные выемки на боковом краю (рис. 4,12 ) и оформлено двумя концевыми сечениями. Третье орудие - небольшое, с двумя клектонскими выемками и косым сечением (рис. 8, 4). Последнее орудие фрагментировано, имеет выемку от вентрального фаса, комбинировано с выступом на углу площадки с поперечной резцевидной кромкой, оформленной микрофасетками.

Зубчатые скобели - 3 шт. Все изготовлены из обломков. Первое и 
одно из самых выразительных орудий в коллекции оформлено по периметру четырьмя толстыми сечениями, лезвие - от глубоких полукрутых фасеток отёсывающей ретуши (рис. 7, $2)$; с боков лезвие ограничено серией нижних фасеток. Второе орудие также оформлено сечениями и имеет аналогичное лезвие (рис. 4, 11), комбинированное с выпуклым зубчатым режущим лезвием, расположенным в нижней части орудия между двумя широкими сечениями. Ещё одно орудие имеет тонкое боковое лезвие (напротив обушка-грани), оформленное пологой нестандартной ретушью; в нижней части - два косых сечения.

Зубчатые ножи и режущие орудия - 2 шт. Орудия изготовлены из отщепов. Короткий нож с боковым натуральным обушком имеет выпуклое зубчатое лезвие (4,7 см) с дорзальными полукрутыми чешуйчатыми фасетками (рис. 4, 9); лезвие ограничено с боков небольшим дистальным сечением и в базальной части - вентральной выемкой-фасеткой. Другое изделие изготовлено из плоского отщепа и имеет зубчатое режущее лезвие по всему периметру, зубчики оформлены серией небольших выемок-фасеток; орудие имеет одно сечение.

Ножи - 13 шт. Это в основном ножи (отщепы) с боковым обушком: натуральным (4 шт.) или с гранью (7 шт.). Наиболее простая форма представлена ножом с отсечённой площадкой (рис. 4, 4), более сложная - с утончённым фасетками основанием и косым дистальным сечением (рис. 4,7 ), либо в комбинации с ретушированными выемчатыми скобелями в дистальной части, оформленными кроме того сечениями (рис. 4, 3); в последнем случае орудие изготовлено из удлинённого отщепа, снятого с помощью посредника (центральный дорзальный фас также снят от посредника). Одно изделие изготовлено из широкой пластины при помощи четырёх сечений и выемок-фасеток (рис. 6, б). Ещё один нож имеет привершинную площадку и прямое боковое лезвие, оформленное альтернативной разнофасеточной ретушью.

Режущие орудия - 39 шт. К этой самой многочисленной группе отнесены орудия с одним, реже двумя острыми (режущими) участками на краях, дополненными 1-2 сечениями (рис. 4, 10), а иногда - отдельными или серией фасеток на краю. У девяти изделий на лезвии наблюдаются микровыемки-фасетки, иногда придающие последнему мелкий зубчатый характер; у пяти - сами лезвия с одного или обоих боков выделены выемкой-фасеткой (рис. 8, 10). У одного орудия основание на месте площадки утончено двухсторонними фасетками, у другого - площадка удалена вентральным фасом, у третьего - площадка отсечена. Одно орудие комбинировано с угловым резчиком. Ещё у трёх орудий помимо сечения на краю наблюдаются отдельные фасетки ретуши.

Сечёные формы отщепов 14 шт. Орудия данной группы во многом сходны с режущими орудиями, но отличаются меньшими размерами - длина их обычно не превышает 4 см. Здесь представлены концевые дистальные формы (6 шт.), средние (7 шт.) и базальные (1 шт.). Последнее изделие с одним скошенным сечением и боковым острым лезвием несёт признаки утончения бюльба вентральной фасеткой (рис. 8, 7), что предполагает возможность использования его как вкладыша. Ещё одно изделие - укороченное среднее сечение ослож- 
нено двумя боковыми выступами, оформленными выемками-фасетками (рис. 8, 2). Некоторые сечения имеют геометрические формы: подтреугольную (3 шт.), параллелограмма (1 шт.) и неправильной трапеции (1 шт.).

Вкладышевые орудия - 15 шт. Сюда относятся разные формы. Рассмотрим, прежде всего, изделия с острым лезвием и противоположным широким основанием, которое, как мы предполагаем, предназначалось для вкладывания в боковой паз метательного оружия (5 шт.). Наиболее интересны здесь два изделия. Первое имеет подтреугольную ассиметричную форму со скошенным острым лезвием, осложнённым выемкой и фасетками ретуши (рис. 7,7 ); основание широкое прямое в виде плоскости сечения. Размеры $-7,0 \times 5,1 \times 1,7$ см. Второе изделие имеет высокую сегментовидную форму с дугообразным острым лезвием с частичной ретушью (рис. 7, 8), основание такое же сечёное; изделие утончено плоскими односторонними фасетками, направленными от обушка. Размеры $7,3 \times 5,8 \times 1,4$ см. С ним сходно другое высокое сегментовидное изделие с дугообразным острым лезвием со следами ретуши и с выемками-фасетками (рис. 8,8 ); обушок широкий прямой сечёный. Размеры - 4,3×3,5×0,8 см. Ещё одно изделие имеет подпрямоугольную форму с обушком-гранью в основании (рис. 7, б), оно оформлено тремя сечениями и вентральной чешуйчатой ретушью на краю, а также небольшими фасетками утончения основания от обушка; на боковом выступе - тонкие резцовые сколы. Размеры - 5,4×4,2×1,1 см. Последнее изделие высокой сегментовидной формы с дугообразным лезвием, осложнённым ретушированной выемкой, и с широким прямым основанием, оформленным фасетками частично с двух сторон (рис. 5,1 ); размеры $7,2 \times 6,1 \times 1,4$ см.

Помимо такого рода изделий в коллекции представлены вкладыши с узким основанием для насада в торец рукоятки или метатального оружия. Одно такое изделие имеет узкое острое поперечное лезвие на конце, оформленное на месте площадки небольшими дорзальными фасетками. Оно изготовлено из короткого и тонкого отщепа, насадом служил дистальный сечёный конец, а на боковом краю двумя небольшими вогнутыми сечениями оформлен зубчатый «рогатый элемент» с парой острых выступов; размеры $-5,3 \times 3,0 \times 0,4$ см, показатели удлинённости - 1,77 и массивности $-0,13$.

Остальные изделия относятся к группе остроконечных вкладышей в торец составной основы. Они делятся на две группы в зависимости от характера заострённого окончания: в виде массивного выступа, трёхгранного в сечении (4 шт.), и в виде более тонкого острия (5 шт.). Среди первых отметим, прежде всего, изделие из короткого отщепа с широким ассиметричным пером и поперечной кромкой $(1,2$ см) на окончании, оформленными с боков сечением и притупливающей ретушью, а с брюшка - фасетками; на боковом краю отретуширована широкая выемка, насадом выступает дистальное концевое сечение (рис. 8, 6). Размеры - 4,7×3,6×1,2 см, показатели удлинённости - 1,31 и массивности 0,33. Ещё у одного изделия остроконечный выступ оформлен вентральным фасом на углу площадки, верхняя часть утончена вентральными фасетками, насад тонкий и с косым сечением; размеры - 6,3×4,4×1,4 см, 
показатели удлинённости - 1,43 и массивности - 0,32. Остальные два изделия этой группы изготовлены из укороченных отщепов, причём остроконечный выступ располагается на относительно толстом боковом краю, а насад - на противоположном тонком краю. У одного выступ оформлен широким косым сечением, у другого - тремя толстыми сечениями, у обоих - насад подработан микросечениями, фасетками и выемками-фасетками. Размеры у первого $-10,4 \times 6,0 \times 2,2 \mathrm{~cm}$, а также 1,73 и 0,37 и у второго $8,7 \times 5,5 \times 2,4$ см, а также 1,58 и 0,44.

Среди изделий с тонким остроконечным окончанием один образец изготовлен из удлинённого плоского отщепа, остриё - с микроретушью, на боковом краю - острый шип, базальная часть сужена вентральными фасетками. Размеры - 7,3×3,2×1,1 cм, а также 2,28 и 0,34. Два других изделия - из коротких желобчатых сколов. У одного остриё оформлено небольшим сечением и двумя выемкамифасетками, а черешок на месте тонкой изогнутой площадки; размеры $-5,8 \times 3,2 \times 0,9$ см, а также 1,81 и 0,28 . Второе изделие в форме ромба с сечением и дорзальной притупливающей ретушью на краю, насад - с крутой вентральной фасеткой. Размеры $-4,8 \times 4,1 \times 0,5$ см, а также 1,17 и 0,12 . Остальные два изделия - из укороченных сколов. У одного удлинённо треугольного изделия остриё оформлено на боковом краю косым сечением и дорзальной фасеткой, размеры - 7,2×3,2×1,1 см, а также 2,25 и 0,34 . У другого - подтреугольного изделия остриё с косым микросечением и острым шипом сбоку, размеры $5,6 \times 3,8 \times 0,6$ см, а также 1,47 и 0,16.

Орудия с выступами - 29 шт. У большинства из них (18 шт.) на- блюдаются два и более выступов, т.е. комбинации рабочих элементов (частей) одинаковых или различных функциональных назначений. К угловым резчикам, у которых на выступах имеется острая продольная или диагональная кромка, относятся 12 изделий. Оформление выступа и рабочей кромки велось с боков ретушированными выемками (рис. 7, 5, 9), различными фасетками (рис. 4,2 ), выемками-фасетками (рис. 5, 3) и ретушью и сечениями. Одно орудие изготовлено из черепаховидного отщепа (рис. 4, 2). Имеются комбинации резчика с другими рабочими частями. На втором месте (6 шт.) находятся орудия с массивными остроконечными и трёхгранными в сечении выступами, оформленные весьма скупо отдельными фасетками и сечениями. Некоторые из этих орудий могли выполнять рубящие функции. Ещё одну форму представляют орудия с выступами скребущего профиля (5 шт.), для которых более характерна крутая односторонняя ретушь на выступе, оформленном с боков выемками и сечениями. Орудий с элементом шиповидного выступа-проколки - 4 шт. Резцевидные орудия - 2 шт. У последних присутствует узкая режущая кромка на выступе, но резцовые сколы обычно маловыразительны. Таким образом, «орудия с выступами» - здесь достаточно широкая и разнообразная категория орудий, включающая помимо описанного ещё режущие рабочие части, неровные ретушированные скребущие части, элементы углового резака.

Отщепы с ретушью - 6 шт. Здесь представлены маловыразительные орудия с ретушью на одном или нескольких краях - ретушь обычно непротяжённая, краевая, чешуйчатая, 
или отдельными фасетками с одной или двух сторон.

\section{Заключение}

Как видим, индустрия нижнего горизонта Экибастуз-4 достаточно специфична. В первичном расщеплении здесь наблюдается сочетание нижне-среднепалеолитических приёмов снятия отщепов с помощью тяжёлого и лёгкого отбойников, в частности обушковых и черепаховидных форм, и верхнепалеолитических приёмов снятия пластин, в том числе с помощью посредника. В комплексе орудий отсутствуют типичные мустьерские остроконечники, скрёбла, ножи, а также типичные верхнепалеолитические формы скребков, острий и резцов; напротив, широко представлены тейякский компонент, техника рассечения заготовок и комбинаторика рабочих частей (элементов) орудий; характерны также крупные, грубо приготовленные орудия, чаще всего с заострённым окончанием, которые могли использоваться для добывания из эоценового пласта сырьевых отдельностей кварцита. Наличие серии специфических вкладышей из отщепов говорит в пользу развитого характера индустрии, по времени, вероятно, соответствующей эпохе верхнего палеолита. Аналогии данной индустрии очевидны - это кварцитовые материалы памятника Дузоке-3 [Волошин, 2011], а также индустрия из мелкообломочной брекчии карбона в Баршин 3 [Волошин, 1982]. На обоих этих памятниках присутствуют бифасы. Отсутствие последних в нижнем горизонте Экибастуза-4, вероятно, случайно и обусловлено незначительным объёмом выборки; о вполне возможном производстве бифасов в данной индустрии свидетельствует наличие здесь орудий с распространённой ретушью (рис. 3,2 ) и характер оформления нуклеусов двухсторонними фасами (рис. 2, 1).

При оценке геологического возраста индустрии отметим, что генерации криогенных клиньев в верхней части отложений, скорее всего, относятся к позднеледниковью, а пылеватая карбонатизированная супесь слоя 5 - к известной «палевой толще» или к преображенским эоловым отложениям Прииртышья, имеющим возраст в пределах 15-17 тыс. л.н. [Кривоногов, 1988, с. 83]. Отмечено, что в сартане южная часть Западной Сибири, в том числе Среднее Прииртышье, входили в область развития дефляционных котловин и эоловых песков [Зыкина, Зыкин, 2012, с. 404]. Принимая во внимание эти обстоятельства, возраст нижнего горизонта Экибастуза-3, вероятно, следует определить как позднекаргинский раннесартанский.

\section{ЛИТЕРАТУРА}

1. Волошин В.C. Местонахождение каменного века Баршин 3 в Тенгизской степи // Вопросы археологии и этнографии Центрального Казахстана. Караганда: изд-во КарГУ, 1982. С. 42-57.

2 Волошин В.С. Палеолитическая стоянка-мастерская Дузоке-3 // Вопросы археологии Казахстана. Алматы: Институт археологии им. А.Х. Маргулана; НИЦИА «Бегазы-Тасмола», 2011. Вып. 3. С. 199-211.

3 Зыкина В.С., Зыкин В.С. Лёссово-почвенная последовательность и эволюция природной среды и климата Западной Сибири в плейстоцене. Новосибирск: «ГЕО», 2012. $477 \mathrm{c}$. 
Волошин B.C. Нижний культурный горизонт памятника каменного века Экибастуз-4

4 Кривоногов С.К. Стратиграфия и палеогеография Нижнего Прииртышья в эпоху последнего оледенения. Новосибирск: Наука, 1988. 231 с.

Сведения об авторе:

Волошин Валерий Степанович - научный сотрудник, Филиал Института археологии им. А.Х. Маргулана (г. Нур-Султан, Казахстан); voloshin49@list.ru

\section{ЕКІБАСТҰ3-4 ТАС ҒАСЫРЫ ЕСКЕРТКІШІНІН ТӨМЕНГІ МӘДЕНИ КӨКЖИЕГІ}

\section{В. С. Волошин}

Мақалада Екібастұз-4 тас ғасыры ескерткішінің сипаттамасы беріледі, стратиграфикалық және геоморфологиялық мәліметтері келтіріледі, 1988 ж. төменгі мәдени қабатын тазалау кезінде алынған сапалы эоцен кварцитті артефактілер жиынтығы суреттелген. Өзіне тән ерекше түрлері бар өндіріс түрлерінің мынандай сипаттамасы беріледі: бастапқы ыдырауда - жаңқалықтарды жарудың төменгіортапалеолиттік әдісінің және тілімшелерді алудың жоғарыпалеолиттік әдістерінің үйлесуі, екінші реттегі ыдырауда - тейяктік құрамдасы, дайындауды қақ бөлу техникасын және жұмыс құралдары бөлшектерінің (элементтерін) комбинаторикасын кеңінен дамыту, жаңқалықтан жасалынған қосалқы саймандардың, сондай-ақ ірі және тұрпайы жарғыш құралдардың ерекше топтамасы. Соңғы каргалық - ерте сартандық секілді өндірістің геологиялық жасының пайдасына дәлелдер келтіріледі.

Түйін сөздер: археология, Екібастұз-4, ескерткіш, өндіріс, құрал, жұмысшы бөлшегі, өңдеме, қабат, жоғарғы палеолит, техника

\section{LOWER CULTURAL HORIZON OF STONE AGE MONUMENT EKIBASTUZ-4}

\section{S. Voloshin}

The article describes the monument of the Stone Age Ekibastuz-4, it provides stratigraphic and geomorphological data, describes the collection of artifacts from the qualitative quartzite of the Eocene, obtained in the cleaning of 1988 from the lower cultural horizon. There is given a characteristic of specific type of the industry for which the following is peculiar: in primary splitting - combination of lower middle paleolithic techniques of flakes cleaving and the upper paleolithic methods of plates removal, in secondary splitting - a Tayac component, widespread development of technology of sectioning of blanks and combinatorial set of working parts (elements) of tools, a series of specific insert tools from flake and also large and rough chopping tools. Arguments are made in favor of the geological age of the industry as late Kargin - early Sartana.

Keywords: archaeology, Ekibastuz-4, monument, industry, tool, working part, retouch, layer, upper paleolithic, technique

\section{REFERENCES}

1. Voloshin, V. S. 1982. In Voprosy arheologii i etnografii Tsentralnogo Kazahstana. (Questions of archeology and ethnography of Central Kazakhstan). Karaganda: Karaganda State University Publ., 42-57 (in Russian). 
2. Voloshin, V. S. 2011. In Beisenov, A. Z. (ed.). Voprosy arheologii Kazahstana (Questions of archeology of Kazakhstan), 3. Almaty: A.Kh. Margulan Institute of Archeology; "Begazy-Tasmola" Publ., 199-211 (in Russian).

3. Zykina, V. S., Zykin, V. S. 2012. Lyossovo-pochvennaya posledovatelnost i evolyutsiya prirodnoy sredy $i$ klimata Zapadnoy Sibiri v pleystocene (Loess-soil sequence and evolution of the natural environment and climate of Western Siberia in the Pleistocene). Novosibirsk: "GEO” Publ. (in Russian).

4. Krivonogov, S. K. 1988. Stratigrafiya i paleogeografiya Nizhnego Priirtyshiya $v$ epohu poslednego oledeneniya (Stratigraphy and paleogeography of the Lower Irtysh Region during the last glaciations). Novosibirsk: "Nauka" Publ. (in Russian).

\section{About the Author:}

Voloshin Valery S. Researcher, Branch of the A.Kh. Margulan Archeology Institute, Nur-Sultan, Kazakhstan; voloshin49@list.ru

\footnotetext{
Мүдделер қақтығысы туралы ақпаратты ашу. Автор мүдделер қақтығысының жоқтығын мәлімдейді. / Раскрытие информации о конфликте интересов. Автор заявляет об отсутствии конфликта интересов.

/ Disclosure of conflict of interest information. The author claim no conflict of interest.

Мақала туралы ақпарат / Информация о статье / Information about the article.

Редакцияға түсті / Поступила в редакцию / Entered the editorial office: 30.10.2019.

Рецензенттер мақұлдаған / Одобрено рецензентами / Approved by reviewers: 06.11.2019.

Жариялауға қабылданды / Принята к публикации / Accepted for publication: 13.11.2019.
} 